\title{
MODELING OF THE DEPENDENCE OF THE PRODUCED AMOUNT OF HYDROGEN GAS (Y) ON THE AMPERAGE OF CELL (X) OF A MARINE DIESEL ENGINE SKL 3NVD24
}

\author{
Hristo Hristov, Ivaylo Bakalov, \\ Bogdan Shopov, Dobromir Yovkov \\ Nikola Vaptsarov Naval Academy (Bulgaria)
}

\begin{abstract}
The introduction of new fuels in the field of maritime transport is considered a serious challenge due to the harsh environmental conditions in which the motor ship must operate. Modern marine engines are designed to improve the overall efficiency of the marine system so any attempt to exploit a new fuel must be accompanied by scientific research and experimental data to provide engineers and ship operators with sufficient information on its efficiency and safety.

Keywords: marine engine; hydrogen; dependence hydrogen gas
\end{abstract}

\section{Introduction}

The purpose of this publication is to present the results of a study on the impact of hydrogen gas on the environmental characteristics of the exhaust gases of a marine diesel engine SKL 3NVD24. Place of the experiment - Naval Academy „N. Vaptsarov” - Varna.

\section{Objective and research methodologies}

The engine used is four stroke inline, atmospherically charged. Piston stroke $-240 \mathrm{~mm}$ and cylinder diameter $-175 \mathrm{~mm}$. The designation 3NVD24 indicates that the engine is 3 cylinder, $\mathrm{N}$ - means that the ratio of stroke of the piston to the diameter of cylinder - is less than 1.3. The letter sign $\mathrm{V}$-indicates that the engine is four-stroke and $\mathrm{D}-$ means that it is a diesel engine. The number after designation is the stroke of the piston in centimeters. The SKL 3NVD24 engine was manufactured in 1965 at the Karl Liebkner plant in Magdeburg in the former German Democratic Republic.

The engine's fuel system includes fuel filters, fuel pumps (one for each cylinder) and fuel valves. The engine oil system includes a crankshaft gear oil pump, coarse and fine filters and a double acting manual piston pump for pre-coupling oil to the 
main and connection rod bearings. The cooling system consists of two circuits, an open circuit in which the circulation of sea water is simulated and a closed circuit with fresh water. If the cooling circuit with fresh water is damaged, the engine can also be cooled with sea water from the open circuit.

A piston pump provides the incoming water to the open cooling circuit and a centrifugal pump provides cooling of the cylinder block and the cooling spaces of the cylinder head through water-water cooler. Both pumps are driven by the crankshaft via a gear drive. The engine is started with the help of compressed air at a nominal pressure of 30 bar and a minimum rotation pressure of 12 bar. The nominal speed is $600 \mathrm{~min}^{-1}$ and the minimum speed is $300 \mathrm{~min}^{-1}$. The rated power of the engine is $44.1 \mathrm{~kW}$ or $60 \mathrm{hP}$. The working volume of the cylinders is 17.32 $\mathrm{dm}^{3}$ (5.76 dm $\mathrm{dm}^{3}$ for each cylinder). Stand KI2139B-GOSNITI is designed for testing engines with nominal torque of $25-40 \mathrm{~kg} / \mathrm{m}$ and crankshaft speed of 1500-3000 $\mathrm{min}^{-1}$. As the operating frequency of the engine is $300-600 \mathrm{~min}^{-1}$, to work together with the electric brake, an increasing gear is required. For this purpose, a multiplier with a gear ratio of 1:5 is installed. The supply voltage of the stand is $380 \mathrm{~V}$, the frequency is $50 \mathrm{~Hz}$. The load capacity of the stand is $210 \mathrm{~kW}$. The breaking and torque measuring device is a pendulum-type weighing mechanism.

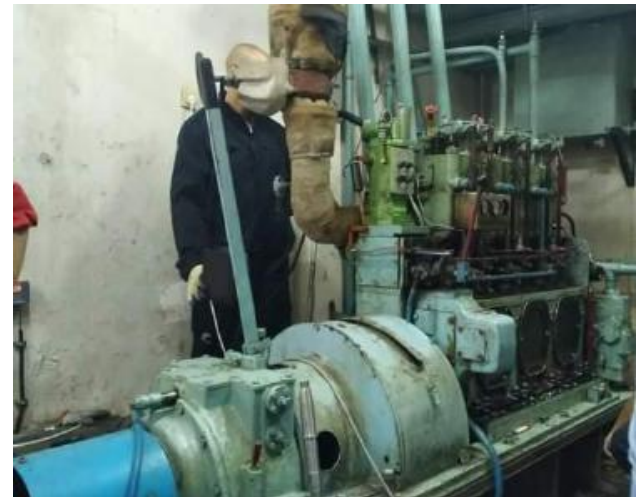

Figure 1. Marine diesel engine SKL3NVD24

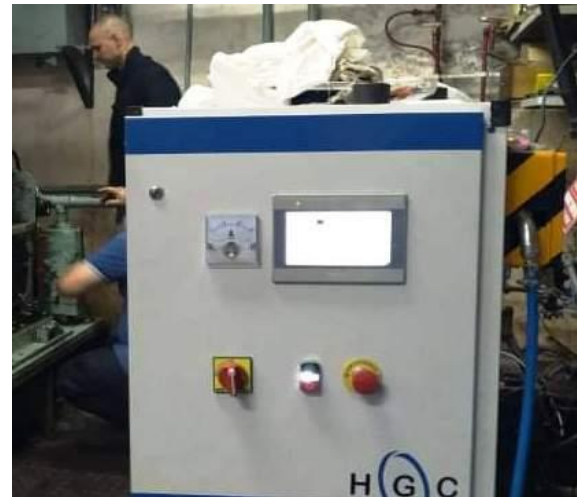

Figure 2. Gas generator

The hydrogen experiment was performed on a VST 4C gas generator, manufactured by Hydrogas. This machine is an oxy-hydrogen gas generator. It produces stoichiometric gas mixture composed of hydrogen and oxygen. The gas mixture is a useful product which in turn is used to clean international combustion engines of any type, size, power, fuel and purpose. The VST-4C is automatic and the operator must set the operating mode limits by providing a front-facing display for this purpose performing command and control functions. The gas generator is 
designed in accordance with the latest technologies and requirements for this type of machine. Its work is completely reliable and safe.

In Table 1. the technical characteristics of the gas generator can be seen.

Table 1. Technical characteristics of the gas generator

\begin{tabular}{|l|l|}
\hline \multicolumn{2}{|c|}{ Model VST 4C } \\
\hline $\begin{array}{l}\text { maximum installed power } \\
\text { /KW/ }\end{array}$ & 6 \\
\hline $\begin{array}{l}\text { maximum gas productivity } \\
\text { (litres/hour) }\end{array}$ & 6500 \\
\hline $\begin{array}{l}\text { maximum consumption } \\
\text { of distilled water (liters/ } \\
\text { hour) }\end{array}$ & 0,5 \\
\hline weight /kilograms/ & 150 \\
\hline dimensions /mm/ & $600 / 1480 / 600$ \\
\hline
\end{tabular}

The experiment was performed while maintaining the same engine temperature with a change in the amount of gas supplied (by changing the current of the hydrogen cell) and registration of components of the exhaust gases (Liang et al. 2017). The experiment is performed at rated speed and without load. It is necessary to specify that all tests and the accompanying conclusions refer only to the specific type of hydrogen cell and the respective engine (Miller et al. 2014; Miao et al. 2021; Sapra et al. 2020). Their summary in different conditions can only be of a principled nature.

In the performed research, a significant difference in the data was found, due to the selected factors and external disturbances (Bakalova et al. 2020). An experimental statistical method - regression analysis was chosen for processing the experimental material. Excerpts from 9 experiments were used. Obtaining qualitative regression models was achieved after performing the following two step procedure: determining the parameters of a pre-selected structure of the model and statistical analysis of the results (Bakalova 2020). The finally selected model can be used to predict the effect of the fuel-hydrogen mixture on the exhaust components (Li et al. 2019). Due to the nature of the operation of the hydrogen cell at the beginning of the study, a regression dependence of the change in the amount of hydrogen gas on the strength of the electric current was obtained (Feili et al. 2020). In all subsequent studies, the amount of hydrogen gas was taken as a factor and the content of gases was taken as a starting point. The results of the research are presented in Tab 2. 
Table 2. Exhaust gas content depending on the amount of hydrogen gas.

\begin{tabular}{|l|l|l|l|l|l|l|l|l|l|}
\hline dimension & $\begin{array}{l}\mathrm{I} \\
\text { try }\end{array}$ & $\begin{array}{l}\text { II } \\
\text { try }\end{array}$ & $\begin{array}{l}\text { III } \\
\text { try }\end{array}$ & $\begin{array}{l}\text { IV } \\
\text { try }\end{array}$ & $\begin{array}{l}\text { V } \\
\text { try }\end{array}$ & $\begin{array}{l}\text { VI } \\
\text { try }\end{array}$ & $\begin{array}{l}\text { VII } \\
\text { try }\end{array}$ & $\begin{array}{l}\text { VIII } \\
\text { try }\end{array}$ & $\begin{array}{l}\text { IX } \\
\text { try }\end{array}$ \\
\hline $\begin{array}{l}\text { amperage } \\
\text { (A) }\end{array}$ & 40 & 50 & 60 & 70 & 80 & 90 & 100 & 110 & 120 \\
\hline gas & 3 & 3.3 & 3.2 & 3.6 & 4.3 & 4.3 & 4.8 & 5 & 5.1 \\
\hline diesel & 36 & 38 & 33 & 38 & 39 & 40 & 37 & 38 & 42 \\
\hline $\mathrm{CO}$ & 14.45 & 14.49 & 16.4 & 16.5 & 16.7 & 16.8 & 17 & 17.1 & 17.2 \\
\hline $\mathrm{CO}$ r & 2.4 & 2.4 & 2.3 & 2.4 & 2.4 & 2.5 & 1.7 & 1.8 & 1.7 \\
\hline $\mathrm{NO}$ & 150 & 152 & 90 & 106 & 111 & 118 & 77 & 77 & 80 \\
\hline $\mathrm{O}_{2}$ & 17.8 & 17.8 & 18 & 17.9 & 17.8 & 17.7 & 18.7 & 18.7 & 18.6 \\
\hline $\mathrm{NO}$ & 150 & 152 & 90 & 106 & 111 & 118 & 77 & 77 & 80 \\
\hline qA & 44.2 & 46.1 & 37.3 & 39.5 & 41.5 & 45.7 & 52.6 & 58.3 & 59.1 \\
\hline Eta & 55.8 & 53.9 & 62.7 & 60.5 & 58.5 & 54.3 & 47.4 & 41.7 & 40.9 \\
\hline
\end{tabular}

Table 3. presents the amount of hydrogen gas depending on the amperage of the cell.

Table 3. Amount of hydrogen gas depending on the amperage of the cell

\begin{tabular}{|l|l|l|l|l|l|l|l|l|l|}
\hline dimension & $\begin{array}{l}\mathrm{I} \\
\text { try }\end{array}$ & $\begin{array}{l}\mathrm{II} \\
\text { try }\end{array}$ & $\begin{array}{l}\mathrm{III} \\
\text { try }\end{array}$ & $\begin{array}{l}\text { IV } \\
\text { try }\end{array}$ & $\begin{array}{l}\text { V } \\
\text { try }\end{array}$ & $\begin{array}{l}\text { VI } \\
\text { try }\end{array}$ & $\begin{array}{l}\text { VII } \\
\text { try }\end{array}$ & $\begin{array}{l}\text { VIII } \\
\text { try }\end{array}$ & $\begin{array}{l}\text { IX } \\
\text { try }\end{array}$ \\
\hline $\begin{array}{l}\text { amperage } \\
\text { (A) }\end{array}$ & 40 & 50 & 60 & 70 & 80 & 90 & 100 & 110 \\
\hline gas & 3 & 3.3 & 3.2 & 3.6 & 4.3 & 4.3 & 4.8 & 5 & 5.1 \\
\hline diesel & 36 & 38 & 33 & 38 & 39 & 40 & 37 & 38 & 42 \\
\hline $\mathrm{CO}$ & 14.45 & 14.49 & 16.4 & 16.5 & 16.7 & 16.8 & 17 & 17.1 & 17.2 \\
\hline $\mathrm{CO}$ & 2.4 & 2.4 & 2.3 & 2.4 & 2.4 & 2.5 & 1.7 & 1.8 & 1.7 \\
\hline $\mathrm{NO}$ & 150 & 152 & 90 & 106 & 111 & 118 & 77 & 77 & 80 \\
\hline $\mathrm{O}_{2}$ & 17.8 & 17.8 & 18 & 17.9 & 17.8 & 17.7 & 18.7 & 18.7 & 18.6 \\
\hline $\mathrm{NO}$ & 150 & 152 & 90 & 106 & 111 & 118 & 77 & 77 & 80 \\
\hline $\mathrm{qA}$ & 44.2 & 46.1 & 37.3 & 39.5 & 41.5 & 45.7 & 52.6 & 58.3 & 59.1 \\
\hline $\mathrm{Eta}$ & 55.8 & 53.9 & 62.7 & 60.5 & 58.5 & 54.3 & 47.4 & 41.7 & 40.9 \\
\hline
\end{tabular}

The results of the application of the regression analyses are given in Table 4.

Table 4. Results obtained from mathematical modeling

\begin{tabular}{|c|c|c|c|c|c|c|}
\hline type of model & $\begin{array}{l}\text { coefficient of the } \\
\text { model }\end{array}$ & $\begin{array}{l}\text { adequacy of } \\
\text { the model }\end{array}$ & $\begin{array}{l}\text { standard } \\
\text { error } \mathrm{S}_{y}\end{array}$ & $\begin{array}{l}\text { coefficient of } \\
\text { correlation }\end{array}$ & $\begin{array}{l}\text { correlation of } \\
\text { the remains }\end{array}$ & $\begin{array}{l}\text { stationarity of } \\
\text { the disp. }\end{array}$ \\
\hline$y=b_{n}+b_{1} x$ & $\begin{array}{l}b_{0}=1.7467 \\
b_{0}=0.029\end{array}$ & yes & 0,18283 & 0,9776 & No & yes \\
\hline$y=b_{n}+b_{1} x+b, x^{2}$ & $\begin{array}{l}b_{0}=1.7839 \\
b_{1}=0.028 \\
b_{2}=0.65 e-005\end{array}$ & yes & 0,19743 & 0,9776 & No & yes \\
\hline$y=b_{n}+b_{,} \ln x$ & $\begin{array}{l}b_{\mathrm{a}}=5.0365 \\
\mathrm{~b}_{2}=2.1051\end{array}$ & yes & 0,23873 & 0,96148 & No & No \\
\hline chosen model & \multicolumn{6}{|l|}{$y=1.7467+0.029 x$} \\
\hline
\end{tabular}

The analysis of the data shows that the linear model is adequate. It gives minimal standard error, high correlation coefficient and satisfaction of the conditions for application of the regression analysis - absence of correlation of 
the residues, constant value of the variance, normal distribution of the residues $\mathrm{e}_{\mathrm{i}}$ and $\sum e_{i} \equiv-2.0872 e-014$, value accepted for zero. It is finally selected to approximate the data and the amount of hydrogen gas produced by the cell current. The following graph compares the actual experimental data $(*)$ and those obtained from the model (-).

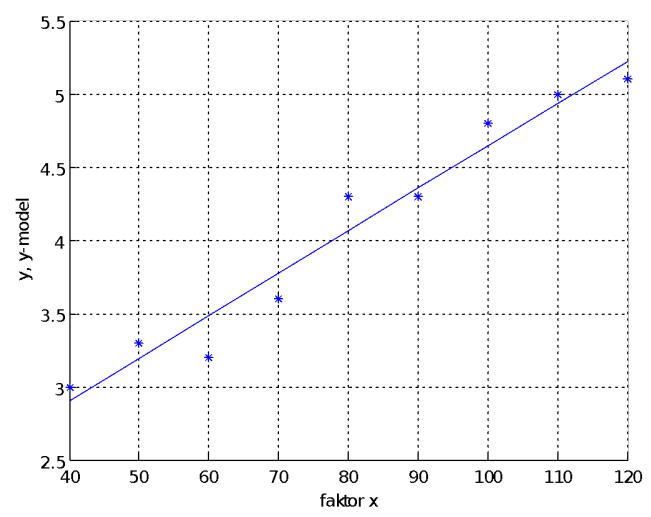

Figure 3. Comparison between experimental data (*) and obtained model (-)

\section{Conclusions}

From the obtained results we can draw the following conclusions:

- Carbon fuel is a good option to replace fuel oil and diesel fuel, which are currently used in marine diesel engines.

- The use of hydrogen fuel can reduce greenhouse gas emissions due to the lower levels of harmful emissions from the use of hydrogen fuel (as shown by experiments)

- The use of hydrogen for maritime purposes will have an impact on reducing global warming and will also have an impact on the eco-toxicity of the environment and sediments in seawater.

\section{REFERENCES}

Bakalova, R., Mihalev D., 2020. Identification of the dynamics of the ratio of foreign direct investment in the northeast region of varna to the total, through one-factor regression models. In: V International Scientific Conference, Summer Session "Industry 4.0". Vol. 1/8, June, pp. 54- 57.

Bakalova, R., 2020. Identification of the relation of the foreign directinvestments in the South-Eastern region of Burgas to the general ones, through one- 
factor regression models. In: V International Scientific Conference, Summer Session "Industry 4.0" 1/8, 58 - 61.

Feili, M., Rostamzadeh, H. \& Parikhani, T., 2020. Hydrogen extraction from a new integrated trigeneration system working with zeotropic mixture, using waste heat of a marine diesel engine.

Liang, J., Zhang, Z. \& Zhong, G., 2017. Numerical study of exhaust reforming characteristics on hydrogen production for a marine engine fueled with $L N G$.

Li, G., Liang, J., Long Y., Zhang, Z. \& Zhang, X., 2019. Performance and emissions characteristics of a lean-burn marine natural gas engine with the addition of hydrogen-rich reformate.

Miller, JW., Pan, H., Princevac, M. \& Pournazeri, S., 2014. Effect of hydrogen addition on criteria and greenhouse gas emissions for a marine diesel engine.

Miao, H., Xia, L., Wang, F., Wang, L. \& Zhang, H., 2021. Design and optimization of hydrogen production by solid oxide electrolyzer with marine engine waste heat recovery and ORC cycle.

Sapra, H., Godjevac, M., De Vos, P. \& Van Sluijs, W., 2020. Hydrogen-natural gas combustion in a marine lean-burn SI engine: A comparative analysis of Seiliger and double Wiebe function-based zero-dimensional modelling.

$\triangle$ Hristo Hristov

ORCID iD: 0000-0003-4990-7132

Ivaylo Bakalov

ORCID iD: 0000-0003-3974-4368

Bogdan Shopov

ORCID iD: 0000-0003-1008-1847

Dobromir Yovkov

ORCID iD: 0000-0003-2958-628X

Nikola Vaptsarov Naval Academy

Varna, Bulgaria

E-mail: hr.hristov@nvna.eu

E-mail: bakalov@nvna.eu

E-mail: shopov@nvna.eu

E-mail: d.jovkov@nvna.eu 